\title{
Cannabis: gyógyszer, élelmiszer vagy kábítószer?
}

\author{
Bajtel Ákos dr. ${ }^{1}$ - Kiss Tivadar dr. ${ }^{1}$ - Csupor-Löffler Boglárka dr. ${ }^{2}$ \\ Szendrei Kálmán dr. ${ }^{1}$. Csupor Dezső dr. ${ }^{1,2}$
}

\author{
${ }^{1}$ Szegedi Tudományegyetem, Gyógyszerésztudományi Kar, Farmakognóziai Intézet, Szeged \\ ${ }^{2}$ Pécsi Tudományegyetem, Általános Orvostudományi Kar, Transzlációs Medicina Intézet, Pécs
}

\begin{abstract}
A kender (Cannabis sativa) gyógyhatásainak megítélése napjainkban változóban van, egyúttal igen ellentmondásos. Munkánk célja a kenderrel és készítményeivel kapcsolatos jogszabályi környezet alakulásának a kender gyógyászati alkalmazásának történetével párhuzamos bemutatása. A kenderrel és tartalomanyagaival kapcsolatos, jelenleg hatályos hazai jogszabályok és nemzetközi egyezmények áttekintése mellett bemutatjuk a kender alkalmazásának történetét a szakirodalmi adatok és a gyógyszerkincs átalakulásának tükrében. A kender ipari pályafutása textilipari alapanyagként kezdődött, de már ezt megelőzően is alkalmazták kábítószerként és gyógyászati célokra. A 20. század során a pszichoaktív szerként való felhasználás vált elterjedtebbé, de a növény hatóanyagainak jobb megismerésével a gyógyászati alkalmazás súlya is nőtt. Jelenleg a kender több vegyülete (kannabidiol, tetrahidrokannabinol) van forgalomban gyógyszerként világszerte, de félszintetikus kannabinoidot (nabilon) tartalmazó készítmények és különböző kannabisztermékek is forgalomban vannak gyógyszerként. Napjainkban alkalmazására jellemző, hogy a racionális gyógyászati használat mellett jelentős a túlzó elvárásokon alapuló, szakszerútlen alkalmazás. Ez részben a kenderrel kapcsolatos jogi szabályozás anomáliáival is magyarázható. Ennek következménye, hogy élelmiszerként elérhetők a kender epilepsziaellenes hatóanyagát tartalmazó termékek, amelyeket számos gyógyhatás reményében használnak orvosi kontroll nélkül. Megállapítható, hogy az új tudományos eredmények, a területen érdekelt vállalkozások céljai, a fogyasztói igények, a piaci realitás és a jogi szabályozás nem minden esetben és szempontból van összhangban. A kannabinoidok hosszabb távú jövőjét a bizonyítékokon alapuló gyógyászatban nagyban befolyásolják azok a kutatások, amelyek segítségével pontosabb kép alkotható haszon-kockázat profiljukról.
\end{abstract}

Orv Hetil. 2021; 162(45): 1808-1817.

Kulcsszavak: kender, Cannabis, tetrahidrokannabinol, kannabidiol, nabilon, dronabinol

\section{Cannabis: medicine, food or illicit drug?}

The opinion about the medicinal value of cannabis (Cannabis sativa) is changing but still remains controversial. The aim of our work was to present the evolution of the regulatory environment of Cannabis and its preparations in parallel with its history as medicine. We reviewed the current national legislation and international conventions on Cannabis and its constituents along with the historical and contemporary medicinal application of Cannabis. The utilisation of Cannabis started in the textile industry, but it was applied for recreational and medicinal purposes beforehand. During the 20th century, it was best known for its psychoactivity whereas its medicinal importance increased after elucidating the bioactivities of the active compounds of the plant. Currently different phytocannabinoids (cannabidiol, tetrahydrocannabinol) are marketed as medicines, but semisynthetic cannabinoids and different cannabis-based products are also approved as medicines. Today, there is a trend that goes beyond the rational and medicinal application thus results in improper form of utilisation. This phenomenon could partly be explained by the anomalies of legislative regulations. As a result, products containing the antiepileptic component of cannabis are available as food and used for different medicinal purposes without medical supervision. Evidently, there is no harmony between the new scientific discoveries, the goals of companies involved, the demands of consumers, market realities and current laws in several aspects. Ongoing studies will help to clarify the benefit-risk profiles of cannabinoids and provide major influence on the future of these compounds in the evidence-based medicine.

Keywords: hemp, Cannabis, tetrahydrocannabinol, cannabidiol, nabilone, dronabinol

Bajtel Á, Kiss T, Csupor-Löffler B, Szendrei K, Csupor D. [Cannabis: medicine, food or illicit drug?]. Orv Hetil. $2021 ; 162(45): 1808-1817$.

(Beérkezett: 2021. február 13.; elfogadva: 2021. április 5.) 


\section{Rövidítések}

5-HT = 5-hidroxi-triptamin; AIDS = (acquired immunodeficiency syndrome) szerzett immunhiányos tünetegyüttes; $\mathrm{CB}=$ (cannabinoid) kannabinoid; $\mathrm{CBD}=$ (cannabidiol) kannabidiol; ENSZ = Egyesült Nemzetek Szervezete; EU = (European Union) Európai Unió; FAAH = (fatty acid amide hydrolase) zsírsav-amid-hidroláz; GPR55 = (G-protein-coupled receptor 55) G-fehérje-kapcsolt receptor-55; HIV = humán immundeficientia-virus; INN = (International Nonproprietary Name) hatóanyagok nemzetközi nem védett neve (nemzetközi gyógyszerszabadnév); MAGL = monoacil-glicerol-lipáz; MÉKISZ = Magyarországi Étrend-kiegészítő Gyártók és Forgalmazók Egyesülete; NÉBIH = Nemzeti Élelmiszerlánc-biztonsági Hivatal; NICE $=($ National Institute for Health and Care Excellence) Az Egészség és Klinikai Kiválóság Nemzeti Intézete, Anglia; NTl = nukleozidtranszporter-1; OGYÉI = Országos Gyógyszerészeti és Élelmezés-egészségügyi Intézet; Ph. Hg. = (Pharmacopoeia Hungarica) Magyar Gyógyszerkönyv; THC = (tetrahydrocannabinol) tetrahidrokannabinol; TRPVl $=($ transient receptor potential cation channel subfamily V member 1 ) tranziens receptor potenciál vannilloid-1; USA $=$ (United States of America) Amerikai Egyesült Államok

A kender (Cannabis sativa L.) az egyik legrégebb óta hasznosított kultúrnövény, amelyet ősidők óta használnak gyógyászati céllal is. Magját és olaját táplálkozási célra hasznosítják, de iparilag (festékgyártásra, fakonzerválásra, valamint a papír-, épító- és textiliparban) is alkalmazzák. A növény hírhedtté válásának oka, hogy világszerte elterjedten alkalmazzák kábítószerként is. Legújabb kori reneszánsza azonban elsősorban növekvő gyógyászati jelentőségéhez köthető. A kender vegyületein alapuló modern gyógyszerek növekvő számát, a tudományos kutatások intenzitását tekintve kijelenthető: a kender gyógyászati jelentősége nagyobb, mint valaha. A következő évtizedekben pedig eldőlhet, helyet követel-e magának tartósan a gyógyszerkincsben.

\section{Az őskortól a legújabb korig}

Világhódító - így is nevezhetnénk, hiszen alig van olyan része a Földnek, ahol ne fordulna elő a kender (Cannabis sativa). Mintegy 10 ezer éves paleobotanikai pollenleletek bizonyítják a Cannabis előfordulását Európában, Románia, Bulgária és Magyarország területén. Európai elterjedésében szerepet játszottak az Ázsiából 3500 évvel ezelőtt érkező szkíta népcsoportok is, amelyek tagjai főleg temetkezési, rituális célból alkalmazták a magok füstjét. Európában ezt követően többfelé elterjedt, de főleg görög és latin történetírók oorizték meg hírnevét. A középkorban Európa-szerte az ipari felhasználása vált jelentőssé, gyógyászati jelentősége csökkent, de nem merült feledésbe, ső́t többen is csodanövénynek tartották. A népi gyógyászatban belsőleg nyugtató, altató, fájdalomcsillapító hatás elérésére, külsőleg sebek, bőrgyulladás kezelésére, kígyó- és kutyamarásra javasolták [1, 2], de mérgező hatását is leírták [3]. A gyógyászatban jel- lemzően a növény herbáját (leveles hajtását) és az abból készített szereket alkalmazták.

A Cannabis európai virágkora a 19. és 20. századra tehető, köszönhetően William B. O'Shaughnessy ír orvosnak és Jacques-Joseph Moreau francia pszichiáternek. O'Shaughnessy indiai tartózkodása alatt készített feljegyzéseket a növény felhasználási formáiról, állatokon figyelte meg a növény toxicitását, és különböző patológiás állapotokban vizsgálta hatékonyságát. A Cannabis használatának Indiában nagy hagyománya van, különböző gyógyászati célokra és élvezeti szerként egyaránt alkalmazzák (az utóbbi célra nemcsak a növény leveleit, hanem a gyantájából nyert hasist is). Moreau módszeresen vizsgálta a Cannabis-készítmények akut hatását önmagán és tanítványain. Moreau és O'Shaughnessy munkája nagy hatással volt a Cannabis és a nyugati orvoslás kapcsolatának alakulására [4].

\section{A kender a hivatalos gyógyászatban a 19-20. században}

A Magyarországon hivatalos gyógyszerkönyvek már a kezdetektól tartalmazták a kendert (Cannabis indica néven) mint gyógyszeralapanyagot. Az 1871-ben megjelent Pharmacopoeia Hungarica I. (Ph. Hg. I.) az erös hatású szerek közé sorolja a kender herbáját és alkoholos kivonatát [5]. 1878-ban jelent meg Balogh Kálmán A Magyar Gyógyszerkönyv kommentárja c. múve, amely az egyes szerek, drogok hatását és használatát is leírja [6]. A Kommentár a Cannabis indica kapcsán megemlíti a növény gyantáját és illóolaját. Leírja, hogy a keleti népeknél az indiai kendert felvidámító, étvágyat gerjesztő, részegítő, álomhozó és „ivarösztönt fokozó” anyagul használták. Hazánkban alkoholos kivonatait vagy a herbájából készült cigarettát használták álmatlanság, migrén, zsábák és köszvény kezelésére, de a mák és készítményei mögött helyezkedett el a terápiás rangsorban. Az 1888-ban kiadott Ph. Hg. II. Cannabis indica cikkelye nem változott az előző kiadáshoz képest, azonban egy Chlorodine nevú, valamikor kolera ellen használt gyógyszer összetételébe is belekerült az indiai kender kivonata [7], amelyet görcsellenes, verejtékhajtó és izgatószerként használtak [8]. Megemlítendő még, hogy a kivonat mellett bekerült a Gyógyszerkönyvbe a Tinctura cannabis indicae is. Bókai Árpád 1891-ben megjelent Újabb gyógyszerek c. múvében ír a Cannabis indica növényről. Megjegyzést tesz arról, hogy hiányosak az ismeretek a növény kémiai összetételét illetően. Az akkoriban új készítményeknek számító Cannabis-alapú gyógyszereket is bemutatja, kezdve a Cannabinum tannicummal, amelyet a Merck gyógyszergyár készített. A készítménnyel kapcsolatban megjegyzi, hogy „megbízhatatlan hatású”. A Cannabinonumot, más néven Haschish purumot hol szedatívumként alkalmazták, hol pedig tiltották szedatívumként történő használatát. Azt is megemlíti, hogy sok esetben erős izgató tünetek jelentkeztek használat közben [9]. Az 1909-ben megjelent Ph. Hg. III.-ban is fel- 
lelhető a növény herbája, valamint két kivonat leírása [10], de a Ph. Hg. IV. (1934) már csak említés szintjén kezeli a Cannabist [11]. A következő gyógyszerkönyvekből a kender és készítményei teljesen hiányoznak.

Vámossy Zoltán 1944-ben megjelent Gyógyszertan c. könyve az ún. csillapítószerek kategóriájába sorolja a Cannabis indicát a bróm és vegyületei, valamint a Radix Valerianae mellett. A Cannabis által kifejtett hatást az alkoholéhoz és a kokainéhoz hasonlítja, mivel szerinte izgalom, élénkség, fokozott mozgékonyság, erotikus exaltációk és színgazdag hallucinációk, csodás harmóniák hallása, hirtelen változó, szomorú és vidám delíriumok után mély álom, esetleg hosszan tartó kataleptikus állapot következhet be $[12,13]$. Issekutz Béla 1957-es Gyógyszertan könyve lábjegyzetként említi az indiai kender hallucinogén hatásait [14]. Ez a hatásprofil egyre kevésbé felelt meg a gyógyszerekkel kapcsolatos elvárásoknak, így nem meglepő, hogy a 20. század közepére a kender elvesztette gyógyászati jelentőségét, készítményei a hivatalos medicinán kívülre szorultak. A század második felében a kender a marihuána és a hasis alapanyagaként kétes hírnévre tett szert. A Cannabis sativát már szinte senki nem tekintette gyógynövénynek, sokkal inkább „könnyű drogok” alapanyagának, és megítélése nagyjából a 20 . század végéig nem változott.

\section{Út a modern gyógyszerré válásig}

A kendert gyakran hozzák párhuzamba a mákkal. A két növény alkalmazási célja részben azonos (fájdalomcsillapítás), ugyanakkor a két növény összevetéséből a kender (egészen a legutóbbi időkig) a legtöbb szempontból alulmaradt. A legújabb korig mindkét növényt kivonatként (illetve a mákot ópiumként, a kendert hasisként is) alkalmazták, viszont mintegy 200 éve a két növény eltérő pályaívet kezdett befutni. A mák fó hatóanyaga, a morfin 1805 óta ismert, és már a 19. század óta tiszta hatóanyagként alkalmazzák a gyógyászatban. Ezzel párhuzamosan feltérképezték az egyéb fó alkaloidokat is, és azok gyógyászati használata is megkezdődött. Az első szintetikus származékok az 1930-as években kerültek forgalomba. Az opiátreceptorokat és az azokon ható endogén anyagokat az 1970-es években írták le, és ez a felfedezés új lendületet adott az optimalizált hatásprofilú hatóanyagok fejlesztésének [15]. A morfin és néhány fontos mákalkaloid máig a gyógyszerkincs fontos része, és különösen a súlyos fájdalomcsillapításban ma sincs versenytársa az opioidoknak. A kender kezdettől hátrányban volt a mákkal szemben, ugyanis nem rendelkezett olyan markáns hatásokkal (például fájdalomcsillapítás), mint a mák. Ráadásul, mint erre a 19. század végén rámutattak, megbízhatatlan hatású volt, a különböző helyekről és időszakokban begyưjiött minták hatása nagy szórást mutatott. Az első kannabinoidot (CB-t), a kannabinolt 1932-ben azonosították; ezt az 1960-as években követte a kannabidiol (CBD), majd a tetrahidrokannabinol (THC) [1618]. Mára több mint 100 CB-t írtak le a növényből, és ezek hatásprofilja döntően feltáratlan. A kémiai és farmakológiai sokszínúséget jól mutatja, hogy a THC-nek is több (tér)szerkezeti változata található meg a növényben, amelyeknek a hatása is eltérő. A fó pszhichoaktív vegyület a (-)-transz- $\Delta^{9}$-THC, a THC egyes izomerjeinek viszont nincs ilyen hatásuk. Mivel a kender kémiailag igen változékony növény, érthető, hogy a tartalomanyagok nagy száma és mennyiségi ingadozása miatt megbízhatatlan hatásúnak tartották. Ráadásul nem volt olyan hatása, amelynek révén pótolhatatlannak tűnt volna a gyógyászatban. A kenderkivonat orvosi alkalmazásának leáldozni látszott, az 1930-as évektől fokozatosan eltûnt a gyógyszerkincsből.

A modern gyógyászati felhasználás irányába tett fontos lépés volt az endokannabinoidrendszer és a kannabinoidreceptorok felfedezése az 1980-as évek végén. Nagy részben ennek is köszönhető, hogy a kender kémiai, farmakológiai és klinikai vizsgálatai során a korábban elsődleges jelentőségű (és az élvezeti célú alkalmazás alapjául szolgáló) THC mellett egyéb hatóanyagokra is figyelem irányult. Áttörést jelentő felfedezés volt, amikor igazolták, hogy a THC pszichoaktív hatásai a $\mathrm{CB}_{1}$-receptoron hatva alakulnak ki; ez az ún. endokannabinoidrendszer része, amelynek tagja még a $\mathrm{CB}_{2}$-receptor. Megjegyzendő, hogy a CB-receptorok felfedezése megelőzte az endogénligandok, az endokannabionoidok felfedezését. Az endokannabinoidok, például az anandamid és az arachidonoil-glicerin, valamint az endokannabinoidokat metabolizáló enzimek, a zsírsav-amid-hidroláz (FAAH) és a monoacil-glicerol-lipáz (MAGL), szintén az endokannabinoidrendszer részei [19]. Az endokannabinoidrendszer múködése messze túlmutat a pszichés múködés befolyásolásán, és egyre világosabbá válik, hogy a növényi CB-k hatása is jóval komplexebb, mint a CB-receptorok aktiválása vagy gátlása.

A 2000-es évek táján a klinikumban egyre több helyen váltak elérhetővé szintetikus CB-analógok. Az ezredfordulón a nabilon és a levonantradol antiemetikus alkalmazása túnt perspektivikusnak, bár úgy gondolták, hogy a CB-származékoknál kedvezőbb hatásúak a 5 - $\mathrm{HT}_{3}$-antagonisták [20]. Később a dronabinol (a THC INN neve) hányáscsillapító és étvágyfokozó hatása (AIDS-es betegeknél) [21], valamint a szintetikus THC-analógoknak a krónikus fájdalmak és a sclerosis multiplexhez társuló izommerevség kezelésében betöltött hatása is perspektivikusnak tünt [22]. A modern terápiában az eddigi említett hatóanyagok mellett a nabiximol jelenik meg, a csak spasticitasban hatékony, centrális támadáspontú izomrelaxánsok terápiás alternatívájaként. A legfrissebb tankönyvekben már történelmi példaként szerepel a szelektív $\mathrm{CB}_{1}$-receptor-blokkoló rimonabant, amely 2006 és 2009 között volt forgalomban az EU-ban [23]. Ezt a szintetikus hatóanyagot, bár kiváló testsúlycsökkentő vegyületnek bizonyult, kivonták a forgalomból, mert fokozta a pszichiátriai mellékhatások, a depresszió és az öngyilkosság kockázatát. Nem ez az egyetlen zsákutca a CB-k gyógyászati alkalmazásában: ma már nem tünik re- 
álisnak a THC alkalmazása szembelnyomás csökkentésére és hörgtágítóként sem [24], több gyógyszerjelölt, például a levonantradol elbukott a fejlesztés valamelyik lépcsőjén.

Napjainkban több, a kender hatóanyagait tartalmazó, klinikailag igazolt hatású gyógyszer van forgalomban világszerte (1. táblázat). Ezek egyrészt természetes vegyületeket, másrészt tiszta formában félszintetikus származékokat, harmadrészt pedig standardizált növényi kivonatot tartalmaznak. A dronabinol szintetikusan előállított THC, amely a Marinol és Syndros gyógyszerek hatóanyaga $[25,26]$. Engedélyezett indikációja szintén kemoterápiával társuló hányinger, illetve AIDS-szel járó étvágytalanság. Szintetikus THC-analóg a nabilon, amelyet a Cesamet és Canemes nevü készítmények tartalmaznak, és kemoterápiával társuló hányinger kezelésére használják [27].

Egységesített növényi kivonatot tartalmaz a Sativex nevezetú, szájnyálkahártyán alkalmazott, orálisan adagolható spray, amely azonos mennyiségü THC-t és CBD-t tartalmaz [28]. A Sativex használata sclerosis multiplex esetén fellépó izommerevség ellen javasolt. A hazai gyógyszerkincsben egyedül a kannabidiol hatóanyagot tartalmazó Epidyolex belsóleges oldat található meg és rendelhető szakorvos által. Az Epidyolex a CBD-t $100 \mathrm{mg} / \mathrm{ml}$-es koncentrációban tartalmazza; klobazámmal együtt Lennox-Gastaut-szindrómában és Dravetszindrómában használják antiepileptikumként, kiegészítő kezelésben, az egész EU-ban, mivel centrálisan törzskönyvezett készítményről van szó [29].
Az első kendertartalmú gyógyszereket az 1980-as években engedélyezték az USA-ban; Európában csak az 1990-es évek végén jelentek meg a termékek hivatalos medicinaként, alkalmazásuk pedig csak a 2010-es években vált széles körûvé. Ebben a folyamatban mérföldkő volt 2019, amikor az Európai Gyógyszerügynökség centrálisan (azaz az EU összes tagállamában) engedélyezte az Epidyolex alkalmazását gyógyszerként. A pszichoaktív vegyületeket (dronabinol, azaz THC és nabilon) tartalmazó készítmények ugyanakkor ez idáig tagállami hatáskörben kerültek engedélyezésre. A legszélesebb körben, a tagállamok többségében a nabiximolt (THC és CBD 1 : l arányú elegye) tartalmazó termék érhető el. A dronabinolt vagy nabilont tartalmazó gyógyszerek jelenleg csak néhány európai országban vannak forgalomban (1. táblázat). A hazánkban gyógyszerként nem engedélyezett gyógyszereket egyedi hatósági engedély alapján lehet felírni a betegeknek [30].

A forgalomban lévő kenderalapú gyógyszerek gyógyhatásai általában függetlenek a pszichoaktivitástól, ugyanis az utóbbival ellentétben nem a $\mathrm{CB}_{1}$-receptorokon kifejtett agonista hatás révén alakulnak ki. A THC (dronabinol) és a nabilon hányingercsillapító hatásai a CB-receptorokon kifejtett parciális agonista hatás eredményei, és ugyanezt feltételezik a THC/CBD elegy izomspasticitast csökkentő hatásáról. A CBD antiepileptikus hatása ugyanakkor független a CB-receptoroktól. A vegyület feltehetőleg az intracelluláris kalciumszint modulálásával csökkenti a neuronok hiperexcitabilitását, és ez a hatás a GPR55 (G-protein-coupled receptor 55)

1. táblázat | Forgalomban lévő, kannabinoid hatóanyagú gyógyszerek

\begin{tabular}{|c|c|c|c|}
\hline A gyógyszer neve & Hatóanyag & $\begin{array}{l}\text { Gyógyszerként } \\
\text { engedélyezve } \\
\text { az USA-ban (év) }\end{array}$ & Európában gyógyszerként engedélyezve (év) \\
\hline Cesamet & Nabilon & $1985^{\dagger} ; 1992^{*}$ & $\begin{array}{l}\text { Dánia (2004 - egyedi eng.), Horvátország (2015), Írország (?), } \\
\text { Lengyelország (?), Németország (1983 - egyedi eng.), Norvégia (?), } \\
\text { Spanyolország (?), Egyesült Királyság (?) }\end{array}$ \\
\hline Canemes & Nabilon & - & Ausztria (2012), Németország (2017) \\
\hline Marinol & Dronabinol & $1985^{\dagger} ; 1999^{*}$ & $\begin{array}{l}\text { Dánia (2002 - egyedi eng.), Franciaország (2004), Horvátország (2015), } \\
\text { Írország (?), Lengyelország (?), Németország (1998 - egyedi eng.), } \\
\text { Norvégia (?), Spanyolország (?), Svédország (2011) }\end{array}$ \\
\hline Syndros & Dronabinol & 2017 & - \\
\hline Sativex & $\begin{array}{l}\text { Nabiximol } \\
\text { (CBD : THC } 1: 1)\end{array}$ & - & $\begin{array}{l}\text { Ausztria (2012), Belgium (2012), Csehország (2011), Dánia (2011), } \\
\text { Észtország (?), Finnország (2012), Franciaország (2014), Hollandia (2012), } \\
\text { Horvátország (2015?), Írország (2014), Lengyelország (2012), Litvánia } \\
\text { (2012 - csak klinikai vizsgálatban), Luxemburg (2013), Málta (2015), } \\
\text { Németország (2011), Norvégia (2012), Olaszország (2013), Portugália } \\
\text { (2012), Spanyolország (2010), Svájc (2013), Svédország (2011), Szlovákia } \\
(2012-2017), \text { Szlovénia (2014?), Törökország (2016), UK (2010) }\end{array}$ \\
\hline Epidyolex & CBD & $2018^{\ddagger}$ & Centrális engedélyezés az EU tagállamaiban $(2019)^{\ddagger}$ \\
\hline
\end{tabular}

*Étvágyfokozóként AIDS-es betegeknél.

†Hányáscsillapítóként kemoterápiához társuló hányás esetén.

‡Lennox-Gastaut-szindrómában (LGS) és Dravet-szindrómában (DS) előforduló görcsrohamok kezelésére klobazámmal, 2 éves vagy annál idősebb betegek esetén

AIDS = szerzett immunhiányos tünetegyüttes; CBD = kannabidiol; EU = Európai Unió; THC = tetrahidrokannabinol; UK = Egyesült Királyság; USA = Amerikai Egyesült Államok 
és a TRPVI (transient receptor potential cation channel subfamily V member 1) ioncsatornákra, valamint az NTl transzporterre (nukleozidtranszporter-1) kifejtett hatás következménye [31]. A CB-k terápiás felhasználására irányuló kutatások legújabb irányzata az, hogy nem direkt ható $\mathrm{CB}_{1^{-}}$vagy $\mathrm{CB}_{2}$-receptor-ligandokat fejlesztenek, hanem a bontó enzimek (FAAH vagy MAGL) gátlása révén emelik az endokannabinoidszintet és következésképp a receptoraktivációt.

Az USA-ban és több EU-tagállamban a standardizált kenderkivonatot vagy tiszta vegyületeket tartalmazó gyógyszereken kívül ún. magisztrális kenderkészítmények is forgalomban vannak gyógyászati céllal $[32,33]$. Ezek a növény aprított herbáját vagy annak kivonatait, így a CB-k teljes spektrumát tartalmazzák; összetételük ennek megfelelően változatos, hatásosságuk is változó. A fogyasztás módja gyakran a kannabiszszívást idézi, az alkalmazás célja pedig a különböző súlyos betegségekhez (AIDS, daganatos betegségek, krónikus fájdalom, sclerosis multiplex) társuló panaszok enyhítése, az életminőség javítása. Az ún. orvosi kannabisz használatát elsőként az USA egyes tagállamaiban engedélyezték az 1990-es évek közepén sclerosis multiplex, krónikus fájdalom és végstádiumú rosszindulatú daganatos megbetegedés esetén. Ezt követte Kanada (1999), Izrael (2001), majd több európai ország. Kontinensünkön elsőként Hollandiában került forgalomba 2003-ban, ahol a betegek orvosi elóiratra, gyógyszertárból szerezhetik be az ellenőrzött öszszetételü (és támogatás esetén a piaci árnál olcsóbb) kannabiszt. Gyógyászati célra csak a növény virága vagy annak olajos kivonata használható. Az orvosi kannabisz abban az esetben írható fel, ha az orvos megítélése szerint a gyógyszeres terápia elégtelen vagy túl sok mellékhatással jár, de az indikációk köre nem szabályozott [34]. Az utóbbi tíz évben több európai állam (Svájc - 2011; Csehország és Olaszország - 2013; Németország 2017, Egyesült Királyság - 2018) engedélyezte a kannabisz orvosi célú használatát, jellemzően súlyos betegségekben szenvedők kiegészítő kezeléseként. Míg azonban Csehországban csak erre kijelölt orvosok írhatnak fel orvosi kannabiszt, és csak meghatározott betegségekben szenvedőknek (rák, Parkinson-kór, sclerosis multiplex, súlyos psoriasis), addig Németországban a rendelésre jogosultak és az indikációk köre nem szabályozott. Ott egy többéves program keretében, gyakorlatilag hatalmas populációra kiterjedő, nem intervenciós vizsgálatban tanulmányozzák a kender használatának előnyeit és kockázatait. Olaszországban az indikációk köre szabályozott (sclerosis multiplex, krónikus fájdalom, daganatos megbetegedéssel vagy HIV-fertőzéssel társuló hányinger, hányás vagy cachexia), a szert azonban minden orvos rendelheti [35]. A kenderből készült termékekkel kapcsolatos diskurzust nehezíti, hogy a készítmények megítélését döntően befolyásolja a kendernek mint pszichoaktív növénynek a megítélése. Egyéb hatóanyagoknál ritka, hogy civil szervezetek ösztönzik a gyógyszerengedélyező hatóságokat, ráadásul ezek a törekvések sokszor nem is válnak el a kender mint kábítószer legalizálásának sürgetésétől. Bár az EU egyetlen tagállamában sem elfogadott az orvosi kannabisz cigarettaként való fogyasztása (ehelyett szájon át bevehető készítményeket, például olajos kivonatot, teát alkalmaznak), az USA, Izrael, valamint egyes EU-tagállamok gyakorlata miatt némileg elmosódik a gyógyászati és az élvezeti alkalmazás határvonala. Az USA-ban és Izraelben orvosi célú használata esetén is engedélyezett az elszívás. Hollandiában pedig a kannabisz élvezeti célú alkalmazása legális, és sok beteg, a könnyebb hozzáférés okán, nem az orvos által felírt szert, hanem az élvezeti célra forgalmazott termékeket alkalmazza. Ausztriában pedig az orvosi kannabisz alkalmazását nem hagyták jóvá, ugyanakkor alacsony THCtartalmú kendertermékek a kereskedelemben szabadon (még automatákból is) beszerezhetők [35].

Bár a kenderből kinyert hatóanyagok és egyes származékok esetén elegendő bizonyíték van a gyógyszerként való engedélyezéshez, az még nem világos, hogy ezek a készítmények az azonos céllal alkalmazható farmakonokhoz képest rendelkeznek-e olyan előnyökkel, amelyek révén tartósan is piacon tudnak maradni. A 2021 márciusában frissített NICE-irányelv a nabilont felnőttek kiegészítő kezelésére javasolja kemoterápia által kiváltott hányinger vagy hányás ellen olyan esetekben, amikor a konvencionális terápia nem elégséges. Krónikus fájdalom esetén egyetlen CB-alapú szer alkalmazását sem javasolja az ajánlás. Sclerosis multiplexhez társuló spasticitas esetén a CBD és THC 1 : 1 arányú elegyét tartalmazó szerrel 4 hetes kezelést ajánlanak, amely csak akkor folytatandó, ha a tünetek legalább 20\%-os mérséklését eredményezi [36]. Krónikus fájdalom esetén hasonló megállapítást tesz egy kanadai ajánlás, amely a rendelkezésre álló bizonyítékok alapján a nabilont harmadvonalbeli, kiegészítő kezelésnek minősíti, amelyet elsősorban terminális állapotú daganatos betegeknél lehet alkalmazni, egyéb fájdalomcsillapítókkal együtt [37]; ugyanakkor egy Cochrane-elemzés megállapítása szerint krónikus neuropátiás fájdalomban a CB-k és a kannabisz alkalmazásának előnyei felülmúlják a veszélyeket. A CBD-nek a 2 év fölöttieknél való alkalmazását (klobazámmal kombinálva) abban az esetben ajánlja a NICE Lennox-Gastautszindrómában, ha a rohamok gyakoriságának alakulását félévente ellenőrzik, és a kezelést abba kell hagyni, ha a rohamgyakoriság nem csökken legalább 30\%-kal a kezelés megkezdése elötti állapothoz képest [38]. A CB-k hatásosságával kapcsolatos elvárások (például onkológiai betegségeknél) gyakran meghaladják a reálisan várható hatásokat [39].

\section{Kábítószer vagy gyógyszer? A kender a jogszabályok tükrében}

A modern magyarországi joganyagban elsőként a 1930. évi XXXVII. törvénycikkben tesznek említést az indiai kenderről, amely a Genfben 1925-ben kötött „Nemzetközi ópiumegyezmény" becikkelyezéséről szól. Ez a 
kenderre vonatkozóan kereskedelmi korlátozásokat tartalmaz, de nincs benne általános tiltás még a hasisra sem [40]. Nemzetközi szinten a kender megítélését döntően befolyásolta a New Yorkban, 1961-ben az Egyesült Nemzetek Szervezetének (ENSZ) tagállamai által megkötött Egységes Kábítószer Egyezmény [41]. Az egyezmény létrehozásának célja az volt, hogy az egységes nemzetközi kábítószer-ellenőrzési rendszer létrehozásával, a legális forgalmazás szabályozásával és korlátozásával, valamint az illegális gyártás és kereskedelem ellehetetlenítésével megakadályozzák a kábítószerekkel történő visszaéléseket. A kannabisz és a kannabiszgyanta az Egyezmény I. és IV. („tilalmi”) listáján is szerepelt, a heroinnal egy kategóriában. Ennek oka az a vélekedés volt, amely szerint a marihuána használata gyilkossági hajlamokat ébreszt és őrületbe kerget, és ezért még a heroinnál is veszélyesebb drog [42]. A kannabisz korabeli megítélésében az is tükröződik, hogy a növényt, amely hatóanyagainak zöme ismeretlen volt, gyógyászatilag egyáltalán nem tartották hasznosnak. Bár a kender megítélése a következó évtizedekben változott, az Egyezmény rugalmatlansága döntően hozzájárult ahhoz, hogy a kender gyógyászati jellegű és illegális felhasználása öszszemosódjon, megnehezítve az értelmes diskurzust és stigmatizálva a növényt és hatóanyagait. Magyarországon a 0,2\% THC-tartalom fölötti kenderfajták kábítószernek minősülnek, az ezekkel folytatott tevékenység hatósági engedélyhez van kötve [43].

Jelentős mérföldkő volt a pszichotrop anyagokról szóló, Bécsben 1971-ben aláírt egyezmény, amelyet az 1979. évi 25. törvényerejű rendelet hirdetett ki. Ez a dokumentum nem sokkal a kender pszichoaktív hatóanyagának, a $\Delta^{9}$-THC-nek az azonosítása után született, amelyet be is soroltak a pszichotrop vegyületek közé [44]. Ez azt a furcsa helyzetet eredményezte, hogy a kendert a nemzetközi jogban kábítószernek, pszichoaktív hatóanyagát pedig „csak” pszichotrop anyagnak tekintették. Mindezen túl a tiltott teljesítményfokozó szerek és módszerek használata elleni 1989-es egyezmény a tiltott szerek osztályába sorolja a kannabiszszármazékokat, és meghatározza a THC metabolitjának azt a koncentrációját, amely fölött annak jelenléte a vizeletben doppingvétségnek számít [45].

A kender és a CB-k megítélésén rontott azoknak az ún. dizájnerdrogoknak a megjelenése, amelyek CB-receptorokon ható szintetikus vegyületként váltanak ki pszichoaktív hatást. Ezeknek a vegyületeknek a gyártását, forgalmazását nem tiltották jogszabályok, mivel új vegyületként nem tartoztak a nemzetközi kábítószeregyezmények és nemzeti törvények hatálya alá. Ráadásul ezek a vegyületek (az illegális kábítószerekhez képest) relatíve olcsók, sok fogyasztóhoz eljutnak, és mivel toxikológiai szempontból teljesen ismeretlenek, nem ritka a komoly egészségkárosító hatású új származékok megjelenése a piacon [46]. A halálesetek, egészségkárosodások oka gyakran a vegyületek markáns CB-receptor-hatása. Erre reagálva született egy hazai jogszabály, amelynek melléklete tartalmazza az ún. új pszichoaktív anyagok jegyzékét. Ezek tulajdonképpen a dizájnerdrogok hatóanyagai, azaz olyan vegyületek, amelyeknek a kémiai szerkezete és hatása hasonló a már tiltott szerek szerkezetéhez, de a kémiai különbözőség okán ezek a korábbi szabályozás alapján nem illegálisak. A jegyzék a vegyületekre jellemző közös alapvázakat és a konkrét anyagok folyamatosan bóvülő listáját tartalmazza. Ha egy vegyület már ismert, és illegális kémiai alapvázat tartalmaz, az automatikusan illegálisnak minősül [47]. Az új (tiltott) pszichoaktív anyagok jegyzékén 294 olyan vegyület (köztük szintetikus CB-k) szerepel, amelynek forgalmazását nemzetközi egyezmények egyébként nem tiltják [48].

Bár az 1990-es évektől a kenderrel és hatóanyagaival kapcsolatos biomedikális kutatások intenzívebbé váltak, és több gyógyszer is forgalomba került, mindez nem feltétlenül tükröződött a jogszabályok szintjén. Miután a THC terápiás használata egyre szélesebb körúvé vált, az ENSZ a napirendjére vette a hatóanyag kérdését, és a (-)-transz- $\Delta^{9}$-THC-t 1991-ben az 1971-es Egyezmény - teljes tilalmat elrendelő - I. jegyzékéről áthelyezték a II. jegyzékbe (ezen gyógyászatilag is használt anyagok is vannak). Maga a Cannabis növény, valamint az abból készült kivonatok azonban továbbra is nemzetközi tiltólistán voltak az 1961-es Egyezménynek megfelelően. Ebben csak 2020 végén történt változás, amikor az ENSZ Kábítószerügyi Bizottsága megszavazta a kannabisz eltávolítását az 1961-es Egyezmény IV. listájáról, amely a legveszélyesebb kábítószereket tartalmazza. Erre a politikai aktusra azért került sor, mert az 1961-es Egyezmény megszületése óta nagyot változott a kender megítélése, különösen a gyógyászati alkalmazás kiszélesedésével. Továbbá az sem hagyható figyelmen kívül, hogy a kenderkészítmények forgalma egyéb termékkategóriákban, így élelmiszerként is egyre nagyobb volumenúvé vált.

\section{A kender mint élelmiszer}

A jogszabályok alapján a kenderről egy gyógyászati, ipari és illegális élvezeti célokra használható növény képe alakul ki. Jóllehet a kender hatóanyagait tartalmazó gyógyszerek csoportjának egyik képviselője, az Epidyolex Magyarországon engedélyezett szerként elérhető (ld. korábban), speciális indikációja okán kevés beteghez jut el. Relatíve új fejlemény, hogy a kenderból készült ún. CBD-olajok az elmúlt években hihetetlenül népszerúvé váltak, mivel ezeket számtalan különböző betegség kezelésére alkalmas termékként reklámozzák (illegálisan) egyes forgalmazók. Ezek a készítmények jellemzően a kender - herbából/levélből/virágból eredetileg szerves oldószerrel vagy szuperkritikus állapotú szén-dioxiddal készült - kivonatainak az olajos oldatai. A kivonatokat úgy állítják elő, hogy azokban magas legyen a hatóanyagnak tekintett CBD koncentrációja. Az egyéb CB-k szintje általában nem deklarált, kivéve a THC-t, amelynek 
mennyiségét 0,2\% alattinak közlik a termékek csomagolásán, hogy a termék ne ütközzön a kábítószerekkel kapcsolatos jogszabályokba [43]. A CBD-olajok jellemzően étrend-kiegészítőként kerülnek forgalomba. Ezeket a termékeket az OGYÉI tartja nyilván a bejelentési kötelezettség alapján, piacra kerülésüket nem előzi meg engedélyezési aktus.

Jelenleg több száz CBD-olaj van forgalomban: az ezekkel kapcsolatos anomáliák tisztázására született meg az OGYÉI állásfoglalása a kannabidiollal való tevékenységről, amely részletesen foglalkozik a két legismertebb CB-vel (THC és CBD) [49]. A CBD ma Magyarországon (a világ nagy részéhez hasonló módon) nem minősül ellenőrzött anyagnak, és nem tartozik a nemzetközi hatáskörben ellenőrzés alá vont anyagok (kábítószerek) közé. Ez alól vannak kivételek: Franciaországban törvény tiltja a kenderből kivont CBD forgalmazását. Ez azonban az EU bírósága szerint ellentétes az EU-s joggal, amint erre egy nemrég született ítélet is rámutatott [50].

Az OGYÉI külön hatáskörébe tartozik a CBD gyógyszerhatóanyagként, étrend-kiegészítőként, élelmiszerként és kozmetikumként történő felhasználásának ellenőrzése. A hatóság által kiadott útmutató összefoglalja az étrend-kiegészítőként való forgalmazás szabályait és a hatósági álláspontot. A dokumentum kiemeli, hogy a CBD-t tartalmazó étrend-kiegészítők jelölése, megjelenítése és hirdetése nem állíthatja vagy sugallhatja, hogy az étrend-kiegészítő betegségek megelőzésére, kezelésére alkalmas, vagy ilyen tulajdonsága van (ez egyébként mindegyik étrend-kiegészítő esetén érvényes). Az útmutató hivatkozik az étrend-kiegészítőkben alkalmazásra nem javasolt növények listájára (ún. negatív lista), amely szerint a Cannabis fajok felhasználása tiltott, de korlátozással a mag, illetve a kendermagolaj használható: a THC-tartalom a kendermagolajban nem haladhatja meg a $10 \mathrm{mg} / \mathrm{kg}$, a kendermagban pedig a $0,2 \mathrm{mg} / \mathrm{kg}$ értéket; a CBD-tartalom a kendermagban és a kendermagolajban nem haladhatja meg a $25 \mathrm{mg} / \mathrm{kg}$ értéket [51].

A THC-határérték túllépése a kábítószerekkel kapcsolatos szabályozást sérti, a CBD jelenléte más szempontból lehet problémás. Amint az OGYÉI útmutatója is felhívja erre a figyelmet, az EU álláspontja szerint azok a Cannabis sativa kivonatok, amelyekben a CBD dúsítva található meg, ún. új élelmiszernek tekinthetők, azaz közösségi szintű engedélyezésükig jogszerüen nem forgalmazhatók [52]. Az európai újélelmiszer-szabályozás célja, hogy ne kerülhessen olyan termék élelmiszerként forgalomba, amelynek biztonságossága kétséges. Ha egy élelmiszer esetén nem igazolt, hogy az EU területén hagyományosan alkalmazták élelmiszerként, akkor annak biztonságosságát kísérletesen igazolni kell. Amíg ez nem történik meg, engedély nélküli új élelmiszernek minősül. A kenderolaj (a kender magjából préselt olaj) nem új élelmiszer, fogyasztásának sok évszázados hagyománya van. A kendermag ugyanakkor nem (pontosabban alig) tartalmaz CBD-t, ez a vegyület csak a növény más, élel- miszerként nem fogyasztott részeiben található meg. Ennek megfelelően a CBD-t dúsítva tartalmazó ún. CBD-olajok nem engedélyezett új élelmiszereknek minősülnek. Azok a kendermagolajok viszont nem új élelmiszerek, amelyekben a CBD alacsony koncentrációban, tulajdonképpen gyártási szennyezésként van jelen [49].

Bár az OGYÉI 2018-ban kiadott útmutatója egyértelmúen nyilatkozik arról, hogy a CBD-re dúsított termékek jogszerüen nem forgalmazhatók, a termékválasztékra ennek vajmi kevés hatása volt. Jelenleg több száz, deklaráltan CBD-ben dús termék van forgalomban, bár 2021. májusától az új élelmiszerekkel kapcsolatos szabályozás megsértése miatt egyre több készítményt tiltanak be a kormányhivatalok.

A CBD-ben dús termékekkel kapcsolatos anomáliákra reagálva az étrendkiegészítő-gyártók egyesülete (Magyarországi Étrend-kiegészítő Gyártók és Forgalmazók Egyesülete, MÉKISZ) is közzétett egy tájékoztatót. Ebben megerősítik, hogy CBD-vel dúsított étrend-kiegészítők jogszerúen nem forgalmazhatók az EU tagállamaiban, így Magyarországon sem. Felhívják a figyelmet arra is, hogy a CBD megjelölés alkalmazása az olyan termék nevében, amely szignifikáns mennyiségben szándékoltan nem tartalmaz CBD-t, szintén jogsértő, mert ellentétes a fogyasztókkal szembeni tisztességtelen kereskedelmi gyakorlat tilalmáról szóló törvénnyel $[53,54]$.

\section{Következtetés}

A kendert több évezredes története során ipari, gyógyés élelmiszernövényként egyaránt hasznosították. A növény és kivonatai változékony összetételük, megbízhatatlan hatásosságuk miatt, valamint mivel nem voltak nélkülözhetetlenek a gyógyászat számára, a 20. század közepére kiszorultak a medicinából. A kender és vegyületei ezt követően évtizedeken át nemzetközi egyezmények által tiltott anyagok voltak. Ebben az hozott változást, hogy az elmúlt évtizedekben azonosították a kender tartalomanyagait, feltérképezték azok hatásait, valamint felismerték egyes vegyületek gyógyászatilag hasznosítható hatásait. Ma a kender standardizált kivonata és egyes vegyületei (CBD és THC), valamint az utóbbi félszintetikus származéka, a nabilon számos országban gyógyszerként van forgalomban. Mindemellett számtalan élelmiszer, kozmetikum tartalmazza a kender különböző kivonatait úgy, hogy a növényt egészen 2020 végéig a szigorúan ellenőrzött kábítószerek között tartották nyilván a nemzetközi egyezmények szintjén.

A kender igazi növényi kaméleon, amelynek gyógyászati szerepe és megítélése folyamatosan változik [55]. Jelen ismereteink szerint a CB-knek helyük van a gyógyászatban, ugyanakkor a kender termékeinek ellenőrizetlen alkalmazása veszélyeket rejthet. Az évtizedeken át tartó szigorú tiltást követően, a jelenleg tapasztalható lazítás eredményeként a nem pszichoaktív CB-k forgalmazása, használata a szabályozatlanság felé tart. Figyelmeztető lehet, hogy a CB-k zömének toxikológiai profil- 
ja alig feltárt, a nagy népszerúségnek örvendő CBD-t pedig korábban nem jellemző módon, e-cigarettaként is egyre elterjedtebben alkalmazzák [56]. Olyan vegyületeket alkalmaznak egyre szélesebb körben, akár élelmiszerként, amelyeknek markáns farmakológiai hatásai komoly mellékhatások lehetőségét vetítik elöre [57]. A jogalkotás, és különösen a jogalkalmazás csak lassan követi a tudományos ismeretek bővülését és az álláspontok változását.

Anyagi támogatás: A közlemény megírása anyagi támogatásban nem részesült.

Szerzöi munkamegosztás: Cs. D.: A koncepció kidolgozása. B. Á., Cs. D.: A kézirat szövegezése. K. T., Cs.-L. B.: A kézirat szerkesztése, ellenórzése. Sz. K.: A kézirat ellenőrzése. Cs. D.: A kézirat végső változatának jóváhagyása. A cikk végleges változatát valamennyi szerző elolvasta és jóváhagyta.

\section{Érdekeltségek: A szerző́knek nincsenek érdekeltségeik.}

\section{Irodalom}

[1] Grynaeus T. Hemp in the medieval and modern Hungarian medicinal and herbal history. [A kender a középkori és a mai magyarság gyógyító és növényismeretében.] Addiktológia 2005; 4: 45-51. [Hungarian]

[2] Kenéz Á, Gyulai F. Enigmatic seeds from the migration period. In: Liska A, Szatmári I. (eds.) Mysteries of the dark ages: archeological ruins between the 6th and 11th centuries in the Carpathian basin: lectures held in Békéscsaba in 2011. [Talányos magleletek a népvándorlás korából. In: Liska A, Szatmári I. (szerk.) Sötét idők rejtélyei: 6-11. századi régészeti emlékek a Kárpát-medencében és környékén: a 2011-ben Békéscsabán megrendezett konferencián elhangzott előadások.] Békés Megyei Múzeumok Igazgatósága, Békéscsaba, 2012; pp. 339-348. [Hungarian]

[3] Melius P. Herbarium, About the names, nature and use of trees and grasses. [Herbárium: Az fáknak, füveknek nevekről, természetekről és hasznairól.] Kriterion Könyvkiadó, Bukarest, 1979; pp. 434. [Hungarian]

[4] Zuardi AW. History of cannabis as a medicine: a review. Braz J Psychiatry 2006; 28: 153-157.

[5] Hungarian Pharmacopoeia. [Magyar gyógyszerkönyv.] Pesti Könyvnyomda-Részvény-Társulat, Pest， 1871; pp. 90-179. [Hungarian]

[6] Balogh K. Commentaries of Hungarian Pharmacopoeia [A Magyar Gyógyszerkönyv kommentárja.] A Magyar Orvosi Könyvkiadó Társulat Könyvtára 34. Eggenberger-féle Könyvkereskedés, Budapest, 1878; pp. 49-969. [Hungarian]

[7] Hungarian Pharmacopoeia, second edition. [Magyar Gyógyszerkönyv, második kiadás.] Athenaeum r.társ. könyvnyomdája, Budapest, 1888; pp. 126-219. [Hungarian]

[8] Kazay E. Pharmaceutical lexicon - 2nd volume. [Gyógyszerészi lexicon - II. kötet.] Molnár Mihály, Nagybánya, 1900; pp. 29 331. [Hungarian]

[9] Newer medicins. Regarding to the needs of practicing physicians and pharmacist. [Újabb gyógyszerek. Gyakorló orvosok és gyógyszerészek igényeire tekintettel.] Grill Károly császári és királyi udvari könyvkereskedése, Budapest, 1891; pp. 95-97. [Hungarian]
[10] Hungarian Pharmacopoeia, third edition. [Magyar gyógyszerkönyv, harmadik kiadás.] M. Kir. Állami Nyomda, Budapest, 1909; pp. 57-315. [Hungarian]

[11] Hungarian Pharmacopoeia, fourth edition. [Magyar gyógyszerkönyv, negyedik kiadás.] M. Kir. Állami Nyomda, Budapest, 1934; pp. 24-26. [Hungarian]

[12] Vámossy Z, Mansfeld G. Pharmacology - For physicians and medical students. [Gyógyszertan - Orvosok és orvostanhallgatók számára.] Antiqua Rt., Budapest, 1944; pp. 68-469. [Hungarian]

[13] Kleiner D, Mátis E, Ditrói K. About the role of hemp (Cannabis sativa L.) in the Hungarian medicine until its declaration as narcotic. [A kender (Cannabis sativa L.) magyar orvoslásban betöltött szerepe kábítószerré nyilvánításáig.] Farmakognóziai Hírek 2012; 7(24): 2-4. [Hungarian]

[14] Id. Issekutz B. Pharmacology and medication. [Gyógyszertan és gyógyítás.] Medicina Könyvkiadó, Budapest, 1957; pp. 91-92. [Hungarian]

[15] Brownstein MJ. A brief history of opiates, opioid peptides, and opioid receptors. Proc Natl Acad Sci U S A 1993; 90: 53915393.

[16] Cahn RS. Cannabis indica resin. Part III. The constitution of cannabinol. J Chem Soc. 1932; 3: 1342-1353.

[17] Mechoulam R, Shvo Y, Hashish I. The structure of cannabidiol. Tetrahedron 1963; 19: 2073-2078.

[18] Gaoni Y, Mechoulam R. Isolation, structure, and partial synthesis of an active constituent of hashish. J Am Chem Soc. 1964; 86: 1646-1647.

[19] Howlett AC. The cannabinoid receptors. Prostaglandins Other Lipid Mediat. 2002; 68-69: 619-631.

[20] Vizi ESz. (ed.) Human pharmacology. [Humán farmakológia.] Medicina Könyvkiadó, Budapest, 1997; pp. 421-461. [Hungarian]

[21] Fürst Zs. Pharmacology. [Farmakológia.] Medicina Könyvkiadó, Budapest, 2006; pp. 298-681. [Hungarian]

[22] Gyires K, Fürst Zs. Textbook of basic pharmacology. [A farmakológia alapjai.] Medicina Könyvkiadó, Budapest, 2011; pp. 529-634. [Hungarian]

[23] Gyires K, Fürst Zs, Ferdinandy P. (eds.) Pharmacology and clinical pharmacology. [Farmakológia és klinikai farmakológia.] Medicina Könyvkiadó, Budapest, 2020; pp. 283-944. [Hungarian]

[24] Knoll J. Pharmacology. [Gyógyszertan.] Medicina Könyvkiadó, Budapest, 1995; pp. 194-501. [Hungarian]

[25] Food and Drug Administration. Marinol (dronabinol). FDA, Silver Spring, MD, 08/2017. Available from: https://www.accessdata.fda.gov/drugsatfda_docs/label/2017/018651s029lbl.pdf [accessed: March 26, 2021].

[26] Food and Drug Administration. Syndros (dronabinol). FDA, Silver Spring, MD, 05/2017. Available from: https://www.accessdata.fda.gov/drugsatfda_docs/label/2017/205525s003lbl.pdf [accessed: March 26, 2021].

[27] Food and Drug Administration. Cesamet (nabilone). FDA, Silver Spring, MD, May 2006. Available from: https://www.accessdata.fda.gov/drugsatfda_docs/label/2006/018677s01 1lbl. pdf [accessed: March 26, 2021].

[28] Krcevski-Skvarc N, Wells C, Häuser W. Availability and approval of cannabis-based medicines for chronic pain management and palliative/supportive care in Europe: a survey of the status in the chapters of the European Pain Federation. Eur J Pain 2018; 22: $440-454$.

[29] Summary of product characteristics (SmPC) of Epidyolex. National Institute of Pharmacy and Nutriton of Hungary. [Alkalmazási előírás - Epidyolex. Országos Gyógyszerészeti és Élelmezés-egészségügyi Intézet.] Available from: https://www. ema.europa.eu/en/documents/product-information/epidyolex-epar-product-information_hu.pdf [accessed: March 26, 2021]. [Hungarian] 
[30] National Institute of Pharmacy and Nutrition of Hungary - Individual medicine import. [Országos Gyógyszerészeti és Élelmezés-egészségügyi Intézet - Egyedi gyógyszerigénylés. Budapest, 2018. október 4.] Available from: https://ogyei.gov.hu/ egyedi_gyogyszerigenyles/ [accessed: March 26, 2021]. [Hungarian]

[31] Gray RA, Whalley BJ. The proposed mechanisms of action of CBD in epilepsy. Epileptic Disord. 2020; 22: 10-15.

[32] Alharbi YN. Current legal status of medical marijuana and cannabidiol in the United States. Epilepsy Behav. 2020; 112: 107452

[33] Lipnik-Štangelj M, Razinger B. A regulatory take on cannabis and cannabinoids for medicinal use in the European Union. Arh Hig Rada Toksikol. 2020; 71: 12-18.

[34] Knöss W, van de Velde M, Sandvos C, et al. Key elements of legal environments for medical use of cannabis in different countries. Bundesgesundheitsbl. 2019; 62: 855-860.

[35] European Monitoring Centre for Drugs and Drug Addiction. Medical use of cannabis and cannabinoids: questions and answers for policymaking. Publications Office of the European Union, Luxembourg, 2018. Available from: https://www.drugsandalcohol.ie/30034/1/Medical_use_of_cannabis_and_cannabinoids_questions_and_answers_for_policymaking.pdf [accessed: March 26, 2021].

[36] National Institute for Health and Care Excellence. Recommendations. Cannabis-based medicinal products. NICE Guidance. London, 11 November 2019. Last updated: 22 March 2021. Available from: https://www.nice.org.uk/guidance/ng144/ chapter/Recommendations [accessed: March 26, 2021].

[37] McGolrick D, Frey N. Nabilone for chronic pain management: a review of clinical effectiveness and guidelines - an update. Canadian Agency for Drugs and Technologies in Health, Ottawa, 2018; pp. 1-24. Available from: https://www.cadth.ca/nabilone-chronic-pain-management-review-clinical-effectivenessand-guidelines-update [accessed: March 26, 2021].

[38] National Institute for Health and Care Excellence. Recommendations | Cannabidiol with clobazam for treating seizures associated with Lennox-Gastaut syndrome. NICE Technology appraisal guidance [TA615]. London, 18 December 2019. Available from: https://www.nice.org.uk/guidance/ta615/ chapter/1-Recommendations [accessed: March 26, 2021].

[39] Küronya Zs, Martin T, Kiss E, et al. Using cannabis in oncology: facts and myths. [Kannabisz használata az onkológiában: tények és tévhitek.] Orv Hetil. 2020; 161: 1035-1041. [Hungarian]

[40] International Opium Convention, signed at Geneva on 19 February 1925 (incorporated into Hungarian legislation under No. XXXVII/1930) - National Legislation Database. [1930. évi XXXVII. törvény a Genfben 1925. évi február hó 19-én kötött „Nemzetközi ópiumegyezmény” becikkelyezéséról - Hatályos Jogszabályok Gyújteménye.] Available from: https://net.jogtar. hu/jogszabaly?docid=93000037. TV\&searchUrl=/gyorskereso\%3Fpagenum\%3D9 [accessed: March 26, 2021]. [Hungarian]

[41] Single Convention on Narcotic Drugs, signed at New York on 30 March 1961 (incorporated into Hungarian legislation under Legislative Decree No. 4/1965) - National Legislation Database. [1965. évi 4. törvényerejű rendelet a New-Yorkban, 1961. március 30-án kelt Egységes Kábítószer Egyezmény kihirdetéséről - Hatályos Jogszabályok Gyújteménye.] Available from: https:// net.jogtar.hu/jogszabaly?docid=96500004.tvr [accessed: March 26, 2021]. [Hungarian]

[42] Bayer I. Balance sheet: success of failure? 50th anniversary of the Single Convention on Narcotic Drugs, 1961, and evaluation of its effectiveness. [Mérlegen a valóság: siker vagy kudarc? Az 1961. évi Egységes Kábítószer-egyezmény értékelése az 50. évforduló alkalmából.] Gyógyszerészet 2011; 55: 714-724. [Hungarian]
[43] Govermental Decree No. 162/2003 (X. 16.) on the order of cultivation, distribution and use of plants suitable for the production of narcotic drugs - National Legislation Database. [162/2003. (X. 16.) Korm. rendelet a kábítószer elóállítására alkalmas növények termesztésének, forgalmazásának és felhasználásának rendjéről - Hatályos Jogszabályok Gyújteménye.] Available from: https://net.jogtar.hu/jogszabaly?docid= a0300162.kor [accessed: March 26, 2021]. [Hungarian]

[44] Legislative Decree No. 25 of 1979 announcing the Convention on Psychotropic Substances signed in Vienna on 21 February 1971. - National Legislation Database. [1979. évi 25. törvényerejű rendelet a pszichotróp anyagokról szóló, Bécsben az 1971. évi február hó 21 . napján aláírt egyezmény kihirdetéséről - Hatályos Jogszabályok Gyújteménye.] Available from: https:// net.jogtar.hu/jogszabaly?docid=97900025.TVR [accessed: March 26, 2021]. [Hungarian]

[45] Anti-doping Convention, Act LXXVIII of 2003 done at Strasbourg on 16 November 1989 by by the Council of Europe National Legislation Database. [2003. évi LXXVIII. törvény az Európa Tanács keretében Strasbourgban, 1989. november 16-án létrejött, a tiltott teljesítményfokozó szerek és módszerek használata elleni Egyezmény kihirdetéséről - Hatályos Jogszabályok Gyújteménye.] Available from: https://net.jogtar.hu/ jogszabaly? docid=A0300078. TV\&searchUrl=/gyorskereso\%3Fpagenum\%3D6 [accessed: March 26, 2021]. [Hungarian]

[46] Kábítószerügyi Egyeztető Fórumok. Dangerous psychoactive substances! [Veszélyes pszichoaktív anyag!] KEF, Budapest. Available from: http://www.kef.hu/main/hirek/veszelyes-pszichoaktiv-anyag-113 [accessed: March 26, 2021]. [Hungarian]

[47] Government Decree No. 66/2012 (IV. 2.) on activities that can be carried out in relation to narcotic drugs, psychotropic substances, new psychoactive substances, as well as the listing of these substances and amendment of such lists - National Legislation Database. [66/2012. (IV. 2.) Korm. rendelet a kábítószerekkel és pszichotróp anyagokkal, valamint az új pszichoaktív anyagokkal végezhető tevékenységekról, valamint ezen anyagok jegyzékre vételérôl és jegyzékeinek módosításáról - Hatályos Jogszabályok Gyújteménye.] Available from: https://net.jogtar. hu/jogszabaly?docid=a1200066.kor [accessed: March 26, 2021]. [Hungarian]

[48] Minister for Human Capacities Decree No. 55/2014 (XII. 30.) on substances or groups of compounds classified as new psychoactive substances - National Legislation Database. [55/2014. (XII. 30.) EMMI rendelet az új pszichoaktív anyaggá minősített anyagokról vagy vegyületcsoportokról - Hatályos Jogszabályok Gyüjteménye.] Available from: https://net.jogtar.hu/ jogszabaly?docid=Al400055.EMM\&searchUrl=/gyorskereso $\%$ 3Fkeyword\%3D\%2522\%25C3\%259AJ\%2520PSZICHOAKT\%2 5C3\%258DV\%2522 [accessed: March 26, 2021]. [Hungarian]

[49] Position statement of the National Institute of Pharmacy and Nutrition of Hungary (OGYÉI) on activities concerning cannabidiol $(\mathrm{CBD})$. [Az Országos Gyógyszerészeti és Élelmezésegészségügyi Intézet állásfoglalása a cannabidiollal $(\mathrm{CBD})$ való tevékenységre vonatkozóan.] Budapest, 2019. augusztus 29. Available from: https://ogyei.gov.hu/dynamic/Posititon\%20 statement $\% 20$ of $\% 20$ the $\% 20$ OGYEI $\% 20$ on $\% 20$ activities $\% 20$ concerning\%20cannabidiol\%20(CBD).pdf [accessed: March 26, 2021]. [Hungarian]

[50] Court of Justice of the European Union. A Member State may not prohibit the marketing of cannabidiol (CBD) lawfully produced in another Member State when it is extracted from the Cannabis sativa plant in its entirety and not solely from its fibres and seeds. Press Release No 141/20. Publications Office of the European Union, Luxembourg, 19 November 2020.

[51] List of herbs that are not recommended for use in foods and food supplements by the Scientific Advisory Board of the National Institute of Pharmacy and Nutrition. [OGYÉI. Az OGYÉI Tudományos Tanácsadó Testülete által élelmiszerekben, étrend- 
kiegészítőkben alkalmazásra nem javasolt növények.] Available from: https://www.ogyei.gov.hu/etrend_kiegeszitokben_felhasznalasra_nem_javasolt_gyogynovenyek_es_ertekelesuk [accessed: March 26, 2021]. [Hungarian]

[52] Regulation (EU) 2015/2283 of the European Parliament and of the Council of 25 November 2015 on novel food, amending Regulation (EU) No 1169/2011 of the European Parliament and of the Council and repealing Regulation (EC) No 258/97 of the European Parliament and of the Council and Commission Regulation (EC) No 1852/2001. [Az Európai Parlament és a Tanács (EU) 2015/2283. rendelete - (2015. november 25.) az új élelmiszerekről, az 1169/2011/ EU európai parlamenti és tanácsi rendelet módosításáról, valamint a 258/97/EK európai parlamenti és tanácsi rendelet és az 1852/2001/EK bizottsági rendelet hatályon kívül helyezéséről.] Available from: https:// eur-lex.europa.eu/legal-content/HU/TXT/PDF/?uri=CELE X:32015R2283\&from $=$ hu [accessed: 26 March 2021]. [Hungarian]

[53] Act XLVII of 2008 on the Prohibition of Unfair Business-toConsumer Commercial Practices - National Legislation Database. [2008. évi XLVII. törvény a fogyasztókkal szembeni tisztességtelen kereskedelmi gyakorlat tilalmáról - Hatályos
Jogszabályok Gyúijteménye.] Available from: https://net.jogtar. hu/jogszabaly?docid=a0800047.tv [accessed: March 26, 2021]. [Hungarian]

[54] Notification of the Hungarian Dietary Supplement Association about the use of food supplements produced from hemp. [Magyarországi Étrend-kiegészítő Gyártók és Forgalmazók Egyesülete. Tájékoztatás a kenderból elő́llított anyagok étrend-kiegészítőben történő felhasználásáról.] [Hungarian]

[55] Szendrei K, Hunyadi A. Cannabis, a herbal chameleon. [Kannabisz, a növényi kaméleon.] Gyógyszerészet 2012; 56: 84-89 [Hungarian]

[56] Xantus G, Kanizsai PL. Vaping-associated lung injury. [Az e-cigarettázással összefüggésbe hozható tüdőbetegség.] Orv Hetil. 2020; 161: 413-418. [Hungarian]

[57] Orvos P, Pászti B, Topal L, et al. The electrophysiological effect of cannabidiol on hERG current and in guinea-pig and rabbit cardiac preparations. Sci Rep. 2020; 10: 16079.

(Csupor Dezső dr., Szeged, Eötvös u. 6., 6720 e-mail: csupor.dezso@szte.hu)

\section{PÁLYÁZAT}

A Prof. Dr. Romics László Akadémikus Emlékére Alapítvány pályázatot hirdet Magyarországon dolgozó, magyar állampolgárságú, 40 éven aluli orvosok és orvosbiológiai kutatással foglalkozó személyek számára. A nyertes pályázó(k) között $500000 \mathrm{Ft}$ alapítványi adomány, illetve különdijak kerülnek kiosztásra.

A pályázat célja: a klinikai gyógyitás, vagy orvosi tudományos kutatás területén dolgozók kiemelkedő tudományos tevékenységének elismerése.

Előnyt élveznek azok a pályázók, akik az Alapitvány névadójának munkásságát folytatva cardiovascularis és anyagcsere-betegségek területéről nyújtanak be pályázatot.

A pályázat benyújtásának határideje: 2022. február 28. (elbírálásának határideje: 2022. április 30.)

A pályázatot a palyazat@romicsalapitvany.hu e-mail címre elektronikus aláirással ellátva (ügyfélkapuval létrehozott AVDH aláirás is megfelelö), PDF formátumban kell benyújtani.

A pályázatot természetes személy, saját nevében, magyar nyelven nyújthatja be, a pályázati anyag ábrák nélkül maximum 15.000 leütés (karakter) terjedelmü lehet. A pdf fájl mérete nem haladhatja meg a 25 MB-ot. A pályázathoz a fentiekhez azonos módon, külön pdf formátumú fájlban mellékelni kell rövid szakmai életrajzot, a születési idő, lakcím és telefon elérhetőségek megjelölésével. A szakmai önéletrajz végén nyilatkozni kell, hogy a pályázó a közölt személyes adatoknak a Romics Alapitvány által történő kezeléséhez hozzájárul, tudomásul veszi, hogy a Kuratórium minden tagja megismerheti adatait és pályázatát. A pályázatot papíron kinyomtatott formában nem kell megküldeni.

Az Alapittvány adatairól, müködéséröl az alapitvány honlapján - www.romicsalapitvany.hu - található információ.

A cikk a Creative Commons Attribution 4.0 International License (https://creativecommons.org/licenses/by/4.0/) feltételei szerint publikált Open Access közlemény, melynek szellemében a cikk bármilyen médiumban szabadon felhasználható, megosztható és újraközölhető, feltéve, hogy az eredeti szerző és a közlés helye, illetve a CC License linkje és az esetlegesen végrehajtott módosítások feltüntetésre kerülnek. (SID_1) 